\title{
MEASURING THE WELFARE COST OF INFLATION in South Africa: A Reconsideration
}

\author{
Rangan Gupta \& Josine Uwilingye \\ Department of Economics, University of Pretoria
}

\begin{abstract}
In this paper, using the Fisher and Seater (1993) long-horizon approach, the writers estimate the long-run equilibrium relationship between money balance as a ratio of income and the Treasury bill rate for South Africa over the period 1965:02 to 2007:01, and, in turn, use the obtained estimates of the interest elasticity and the semi-elasticity to derive the welfare cost estimates of inflation, using both Bailey's (1956) consumer surplus approach and Lucas's (2000) compensating variation approach. When the results are compared to welfare cost estimates obtained recently by Gupta and Uwilingiye (2008), using the same data set, but basing it on Johansen's $(1991,1995)$ cointegration technique, the values are less than half of those obtained in the latter study. These range from 0.16 percent to 0.36 percent of GDP for the target-band of three percent to six percent of inflation. The paper thus highlights the fact that welfare cost estimates of inflation are sensitive to the methodology used to estimate the long-run equilibrium money demand relationships.
\end{abstract}

Keywords: Long-horizon regression; money demand; welfare cost of inflation

JEL E31; $41 ; 52$

\section{1 \\ Introduction}

In a recent study, Gupta and Uwilingiye (2008) measured the welfare cost of inflation in South Africa, based on estimates of the interest elasticity and semi-elasticity of money demand functions, which were obtained using the Johansen $(1991,1995)$ methodology on quarterly data for M3, GDP and the Treasury bill rate. Given the estimates for the elasticities, the authors then calculated the welfare cost of inflation using Bailey's (1956) consumer surplus approach. Relying on results obtained from the $\log$-log specification of money demand rather than on the semi-log model for the same, ${ }^{1}$ they indicated that the welfare cost in South Africa ranged between 0.34 percent and 0.67 percent of GDP for a band of 3 to 6 percent of inflation, over the period of 1965:02 to 2007:01.

In this paper, we re-estimate the long-run relationship between money balance and interest rate for South Africa, using the same data set and over the same period as that used by Gupta and Uwilingiye (2008), but applying an alternative approach, namely the long-run horizon regression proposed by Fisher and Seater (1993). One of the advantages of using the long-horizon regression approach is that cointegration is neither necessary nor sufficient for tests on the interest rate elasticity of money demand. As in Gupta and Uwilingiye (2008), the coefficients obtained in regression for both alternative money demand specifications, a double-log version originated by Meltzer (1963) with constant elasticity and a semi-log version originated by Cagan (1956) with constant semielasticity of money, are then used to calculate welfare cost of inflation. In addition, the welfare cost of inflation is then estimated using both Bailey's (1956) consumer's surplus approach and Lucas's (2000) compensating variation approach.

The necessity to compare the welfare cost estimates with that obtained by Gupta and Uwilingiye, based on the Johansen (1991, 
1995) methodology, arises from the issue of the sensitiveness of the estimates of the interest elasticity of alternative forms of money demand, based on alternative econometric techniques adopted to estimate the long-run relationship between money balance and the nominal interest rate. Given that welfare cost estimates hinge critically on the estimate of the interest elasticity and semi-elasticity, it is important to check for the robustness of the results obtained using alternative econometric methodologies.

The above claim regarding the need to use alternative estimation techniques to obtain values for interest elasticity and semi-elasticity is not without empirical basis. Basing their study on the long-horizon regression approach proposed by Fisher and Seater (1993), the researchers Serletis and Yavari (2004), in their study dealing with the welfare cost of inflation for Canada and the United States, came up with much smaller figures than those of Lucas (2000), who had indicated that a reduction in the nominal rate from 0 percent to 3 percent would yield a benefit equivalent to 0.90 percent of real income. However, Serletis and Yavari (2005), while repeating the above study for Italy, came up with very similar numbers for the welfare cost they had obtained earlier for Canada and the United States. ${ }^{2}$ The authors indicated that reducing the interest rate in Italy from 14 percent to 3 percent would yield a benefit equivalent to an increase in real income of 0.40 percent. This, in turn, was fairly comparable to their estimates for Canada ( 0.35 percent) and the United States $(0.45$ percent $)$ for the same percentage point reduction in the nominal interest rate. More recently, Serletis and Yavari (2007) estimated the welfare cost of inflation using the Fisher and Seater (1993) approach for seven European economies. The results indicated that, in larger countries like France and Germany, the welfare cost of inflation is much lower than in small countries like Austria, Belgium, Ireland, Italy and the Netherlands. But, importantly, the numbers were fairly comparable with their earlier studies. On the other hand, as based on the Phillips-Ouliaris (1990) test for cointegration, Ireland (2008) found that a 10 percent rate of inflation, when compared with price stability in the United States, would imply a welfare cost of 0.21 percent of income. This figure, although lower than those of Lucas (1981, 2000) and Serletis and Yavari (2004), was in line with Fischer's (1981) findings of 0.30 percent. Clearly, then, apart from sample period and the country under investigation and alternative money demand specifications, welfare cost estimates are sensitive to alternative estimation methodologies. Our need to reconsider the welfare cost estimates obtained by Gupta and Uwilingiye (2008) therefore cannot be overlooked. Table 1 summarises the studies discussed above and includes the methodology, the country and the size of the welfare cost.

Table 1

Summarising the literature

\begin{tabular}{|c|c|c|c|c|}
\hline Study & Country & $\begin{array}{c}\text { Methodology } \\
\text { (Functional form) }\end{array}$ & $\begin{array}{c}\text { Inflation } \\
\text { comparisons } \\
\text { (Nominal } \\
\text { interest rate) }\end{array}$ & $\begin{array}{c}\text { Welfare costs } \\
\text { (percent of GDP) }\end{array}$ \\
\hline Fischer (1981) & USA & Calibration $^{a}$ (Log-log) & 0 to $10 \%$ & $0.30 \%$ \\
\hline Lucas (1981) & USA & Calibration $^{\mathrm{b}}$ (Semi-log) & 0 to $10 \%$ & $0.45 \%$ \\
\hline Lucas (2000) & USA & Calibrationc (Log-log) & 0 to $3 \%$ & $0.9 \%$ \\
\hline $\begin{array}{l}\text { Serletis and Yavari } \\
(2004)\end{array}$ & $\begin{array}{l}\text { Canada and } \\
\text { USA }\end{array}$ & $\begin{array}{l}\text { Fisher and Seater (1993) } \\
\text { Long-horizon (Log-log) }\end{array}$ & $\begin{array}{l}0 \text { to } 3 \% \\
3 \text { to } 14 \%\end{array}$ & $\begin{array}{c}\text { USA:0.18\% } \\
\text { Canada: } 0.15 \% \\
\text { USA: } 0.45 \% \\
\text { Canada: } 0.35 \%\end{array}$ \\
\hline
\end{tabular}




\begin{tabular}{|c|c|c|c|c|}
\hline $\begin{array}{l}\text { Serletis and } \\
\text { Yavari(2005) }\end{array}$ & Italy & $\begin{array}{l}\text { Fisher and Seater (1993) } \\
\text { Long-Horizon (Log-log) }\end{array}$ & 3 to $14 \%$ & $0.4 \%$ \\
\hline $\begin{array}{l}\text { Serletis and } \\
\text { Yavari(2007) }\end{array}$ & Europe & $\begin{array}{l}\text { Fisher and Seater (1993) } \\
\text { Long-horizon (Log-log) }\end{array}$ & 5 to $10 \%$ & $\begin{array}{c}\text { Belgium: } 0.3 \% \\
\text { Austria: } 0.45 \% \\
\text { France: } 0.1 \% \\
\text { Germany: } 0.2 \% \\
\text { Netherlands: } 0.4 \% \\
\text { Ireland: } 0.4 \% \\
\text { Italy: } 0.4 \%\end{array}$ \\
\hline Ireland(2007) & USA & $\begin{array}{l}\text { Phillips- Ouliaris (1990) } \\
\text { Cointegration (Semi-log) }\end{array}$ & 0 to $10 \%$ & $0.21 \%$ \\
\hline $\begin{array}{l}\text { Gupta and } \\
\text { Uwilingiye (2008) }\end{array}$ & South Africa & $\begin{array}{l}\text { Johansen }(1991,1995) \\
\text { Cointegration (Log-log) }\end{array}$ & $\begin{array}{l}0 \text { to } 3 \% \\
3 \text { to } 6 \%\end{array}$ & $\begin{array}{l}0.34 \% \\
0.67 \%\end{array}$ \\
\hline
\end{tabular}

Notes: a: Interest elasticity used 0.25 based on Goldfeld (1971); b: Lucas (1981) uses a value of 5.0 for the interest semielasticity; c: Lucas (2000) uses a value of 0.50 for the interest elasticity.

Given that inflation has an effect on economic activity, and ultimately on people's well-being, as it reduces the purchasing power of money balances when inflation rises, a correct and fair evaluation of the welfare cost of inflation is crucial. This is because inflation creates and amplifies distortions in many areas of economic activity and also has an influence on all decisions of economic agents. Besides, in a country like South Africa, where the central bank targets inflation, it is of paramount importance to investigate how substantial the welfare costs of inflation are under the inflation target zone of 3 to 6 percent currently pursued by the South African Reserve Bank. This would help us decide whether it was necessary to rethink the band of the target in terms of the welfare cost of inflation. To the best of our knowledge, this is the first attempt to measure the welfare cost of inflation for the South African economy, based on the long-run regression approach proposed by Fisher and Seater (1993).

The remainder of the paper is organised as follows: Section 2 provides a brief summary of the theoretical issues regarding the estimation of the welfare cost of inflation; sections 3 and 4 respectively discuss the data and the long-horizon empirical methodology for the estimation of the log-log and the semi-log money demand specifications; Section 4 also presents the empirical estimates for the interest rate elasticity and the semi-elasticity, as well as the welfare cost estimates for the South African economy. Section 5 concludes.

\section{2}

\section{The theoretical foundations}

As indicated by Lucas (2000), money demand specification is vital in determining the appropriate size of the welfare cost of inflation. Lucas (2000) contrasts two competing specifications for money demand. One, inspired by Meltzer (1963), relates the natural logarithm of $m$, a ratio of money balances to nominal income, and the natural logarithm of a short-term nominal interest rate $r$. This can be expressed as follows:

$$
\ln (m)=\ln (A)-\eta \ln (r)
$$

where $A>0$ is a constant and $\eta>0$ measures the absolute value of the interest elasticity of money demand. Another specification, adapted from Cagan (1956), links the log of $m$ to the level of $r$ via the following equation:

$\ln (m)=\ln (B)-\xi r$

where $\mathrm{B}>0$ is a constant and $\xi>0$ measures the absolute value of the semi-elasticity of money demand with respect to the interest rate.

By applying the methods outlined by Bailey (1956), Lucas (2000) transposed the evidence 
on money demand into a welfare cost estimate. Bailey (1956) described the welfare cost of inflation as the area under the inverse money demand function, or the "consumer's surplus", which could be gained by reducing the interest rate from an existing (average or steady-state) value to zero. So if $m(r)$ is the estimated function, and $\psi(m)$ is the inverse function, then the welfare cost can be defined as:

$w(r)=\int_{m(r)}^{m(0)} \psi(x) d x=\int_{0}^{r} m(x) d x-r m(r)$
As shown in Equation (3), obtaining a measure for the welfare cost amounts to integration under the money demand curve as the interest rate rises from zero to a positive value to obtain the lost consumer surplus and then deducting the associated seigniorage revenue $r m$ to deduce the deadweight loss. From Figure 1 below, this essentially implies that the welfare cost of inflation is measured by the area $\mathrm{A}$.

\section{Figure 1}

Welfare cost calculation using bailey's consumer surplus approach

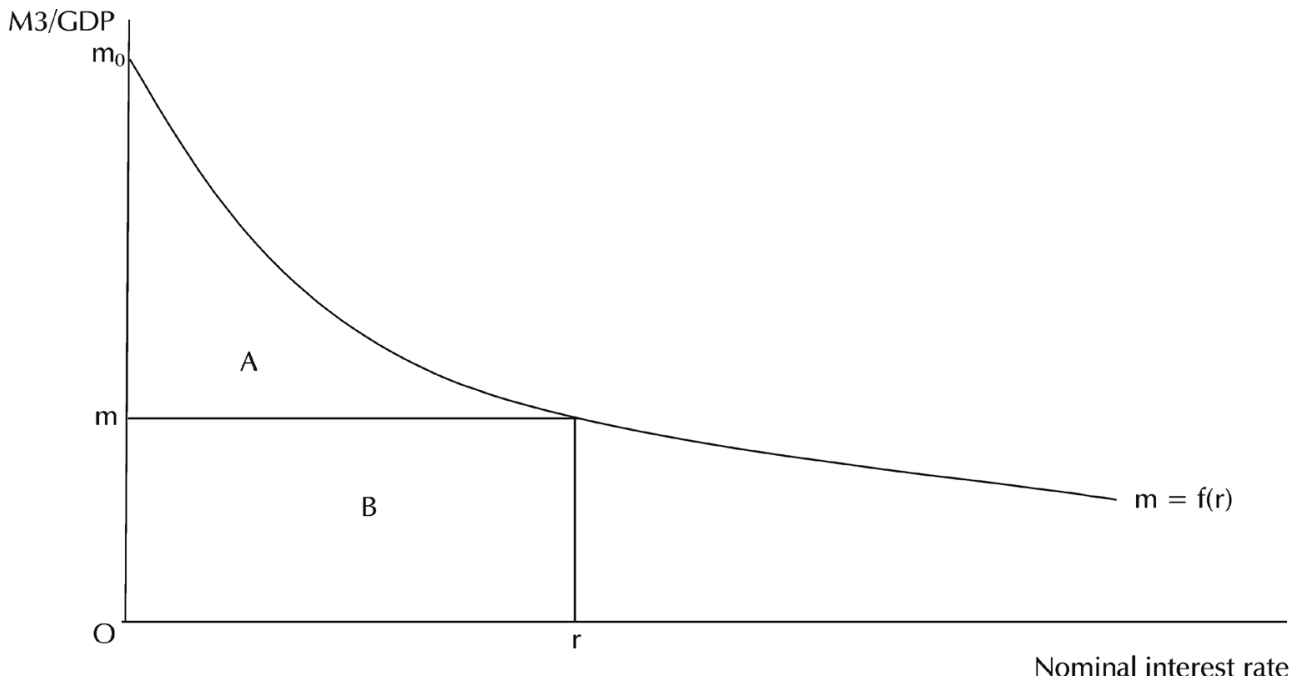

Just as the function $m$ has the dimensions of a ratio to income, so does the function $w$. The value of $w(r)$ represents the fraction of income that people need as compensation, in order to be indifferent between living in a steady-state with an interest rate constant at $r$ or an identical steady state with an interest of close or equal to zero. Given this, Lucas (2000) shows that, when the money demand function is given by (1) or is $m(r)=A r^{-\eta}$, the welfare cost of inflation as a percentage of GDP is obtained as follows:

$w(r)=A\left(\frac{\eta}{1-\eta}\right) r^{1-\eta}$

While, for a semi-log money demand specification i.e., $m(r)=B e^{-\xi r}, w(r)$ is obtained by the following formula:
$w(r)=\frac{B}{\xi}\left[1-(1+\xi r) e^{-\xi_{r}}\right]$

As demonstrated in (4) and (5), an estimate of the interest elasticity of money demand is crucial in evaluating the welfare cost of inflation, so we first have to obtain the long-run relationship between the ratio of money balance to income and a measure of the opportunity cost of holding money, captured by a short-term nominal interest rate.

Besides providing the theoretical general equilibrium justifications for Bailey's consumer surplus approach, Lucas (2000) also takes a compensating variation approach in estimating the welfare cost of inflation. Lucas (2000) starts by using Brock's (1974) perfect foresight version 
of Sidrauski's (1967) Money-in-the-Utility (MIU) model, and defines the welfare cost of a nominal interest rate $r, w(r)$ to be the income compensation needed to leave the household indifferent between living in a steady state with an interest rate constant at $r$ and an otherwise identical steady state with the interest rate of zero with $w(r)$ being obtained from the solution to the following equation: $u[1+w(r) y, \phi(r) y]=u[y, \phi(0) y]$

Realizing that $u$ is also negatively related to the nominal rate of interest, $r$, Figure 2 presents a diagrammatic illustration of what equation (6) essentially implies.

\section{Figure 2}

Welfare Cost Calculation Using the Compensating Variation Approach

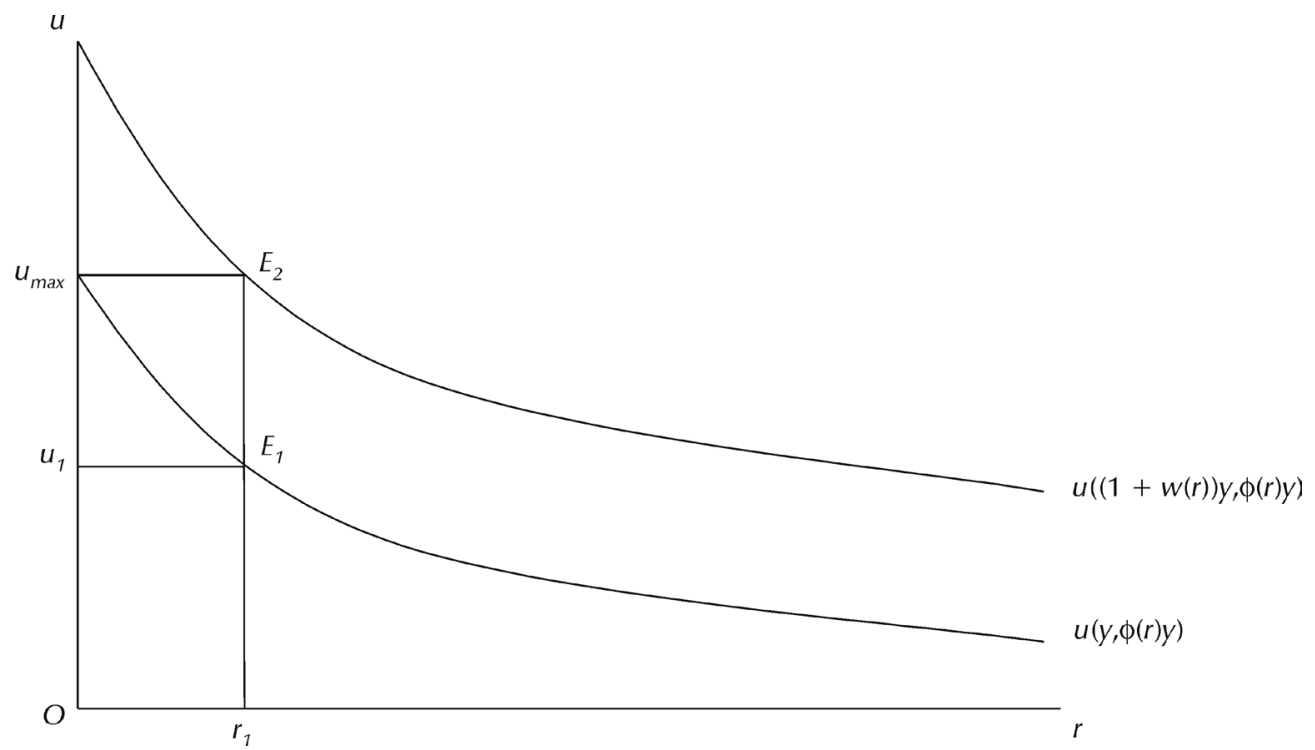

Assuming a homothetic current period utility function $\left(u(c, m)=\frac{1}{1-\sigma}\left[c f\left(\frac{m}{c}\right)\right]^{(1-\sigma)} ; \sigma \neq 1\right)$ and setting up the dynamic programming problem (see Lucas (2000) for details), Lucas obtains a differential equation in $w(r)$ of the following form:

$w^{\prime}(r)=\psi\left(\frac{\phi(r)}{1+w(r)}\right) \phi^{\prime}(r)$

For any given money demand function, Equation (7) can be solved numerically for an exact welfare cost function $w(r)$. In fact, with equation (1), equation (7) can be written as:

$w^{\prime}(r)=\eta A r^{(-\eta)}(1+w(r))^{\frac{1}{\eta}}$

yielding a solution for log-log specification
$w(r)=-1+\left(1-A r^{1-\eta}\right)^{\frac{\eta}{\eta-1}}$

While, for the semi-log model (7) yields

$$
\begin{aligned}
w^{\prime}(r) & =\left[\xi B e^{-\xi_{r}}\left(r+\frac{1}{\xi} \log (1+w(r))\right)\right] \\
& \approx\left[\xi B e^{\xi_{r}}\left(r+\frac{1}{\xi} w(r)\right)\right]
\end{aligned}
$$

with a solution

$w(r)=-e^{\frac{-B e^{-}-\xi r}{\varepsilon}}\left\{e^{\frac{B e^{-}-\xi r}{\xi}}-E i\left[\frac{B}{\xi}\right]+E i\left[\frac{B e^{-\xi r}}{\xi}\right]\right\}$

and where $\operatorname{Ei}(x)=\int_{x}^{\infty} \frac{e^{-t}}{t} d t$, and one uses the principal value of the integral.

Note to calculate $w(r)$, in equations (9) and (11), ${ }^{3}$ we use the estimates of $\eta$ and $\xi$ obtained from the long-horizon regression, discussed in Section 4, while, the values for $A$ and $B$ are 
obtained such that they match the geometric means of the data for the log-log and the semi$\log$ specifications respectively, i.e., $A=\bar{m} /(\bar{r})^{-\eta}$, $B=\bar{m} /\left(e^{-\xi_{r}}\right)$ with $\bar{m}$ and $\bar{r}$ being respectively the geometric means of $m$ and $r$ respectively.

\section{3}

Data

In this study, we use quarterly time series data from the second quarter of 1965 (1965:02) to the first quarter of 2007 (2007:01) for the South African economy, which is obtained from the South African Reserve Bank (SARB) Quarterly Bulletin and the International Financial Statistics of the IMF. The variables used in this study are the money balances ratio (rm3), generated by dividing the broad measure of money supply (M3) ${ }^{4}$ by the nominal income (nominal GDP), and short-term interest rate, in our case, proxied by the 91 days Treasury bill rate $(t b r) .^{5}$ All series, except for the Treasury bill rate, are seasonally adjusted. Further, for the estimation of the log-log specification, both the ratio of money balances and the Treasury bill rate are transposed into their logarithmic values, and are denoted by $l r m 3$ and $l t b r$, respectively.

\section{4}

\section{Empirical methodology and results}

Following Gupta and Uwilingiye (2008), and as it is standard in time series analysis, we start by studying the univariate characteristics of the data. In this regard, we performed tests of stationarity on our variables (lrm3, ltbr and $t b r$ ) using the Augmented-Dickey-Fuller (ADF) test, the Dickey-Fuller test with GLS Detrending (DF-GLS), the Kwiatkowski, Phillips, Schmidt, and Shin (KPSS) test and the Phillips-Perron (PP) test. As observed by Gupta and Uwilingiye(2008), the variables were found to follow an autoregressive process with a unit root, as the null hypothesis of a unit root could not be rejected for the variables expressed in levels for the ADF, the DF-GLS and the PP tests. For the KPSS test, the null of stationarity was rejected. As the variables were found to be non-stationary, it paved the way for the long- horizon regression proposed by Fisher and Seater (1993) to avoid obtaining estimates for the interest rate elasticity and semi-elasticity based on spurious regressions. As stated at the outset, cointegration is neither necessary nor sufficient for this approach, so we do not test specifically for cointegration. ${ }^{6}$

The basics of the long-horizon regression approach can be described as follows, by starting with the following bivariate autoregressive representation:

$\alpha_{m m}(L) \Delta^{(m)} m_{t}=\alpha_{m r}(L) \Delta^{(r)} r_{t}+\varepsilon_{t}^{m}$

$\alpha_{r}(L) \Delta^{(r)} r_{t}=\alpha_{m}(L) \Delta^{(m)} m_{t}+\varepsilon_{t}^{r}$

where $\alpha_{m m}^{0}=\alpha_{r}^{0}=1, \Delta=1-L . L$ is the lag operator, $m$ is the money-income ratio, $r$ is the nominal interest rate, and $\langle x\rangle$ represents the order of integration of $x$, so that if $x$ is integrated of order $\gamma$, or $I(\gamma)$ in the terminology of Engle and Granger (1987), then $\langle x\rangle=\gamma$ and $\langle\Delta x\rangle$ $=\langle x\rangle-1$. The vector $\left(\boldsymbol{\varepsilon}_{t}^{m}, \boldsymbol{\varepsilon}_{t}^{r}\right)$ is assumed to be independently and identically distributed normal with zero mean and covariance $\sum_{g}$, the elements of which are $\operatorname{var}\left(\varepsilon_{t}^{m}\right), \operatorname{var}\left(\varepsilon_{t}^{r}\right)$, $\operatorname{cov}\left(\varepsilon_{t}^{m}, \mathcal{E}_{t}^{r}\right)$. A key result in Fisher and Seater (1993) applies to the case where $\langle m\rangle=\langle r\rangle=1$, which is the case with our data as money balance as $l r m 3, l t b r$ and $t b r$ are all $I(1)$. In this case, the long-run derivative of $m$ with respect to $r$, $\mathrm{LRD}_{\mathrm{m} r}$, is given by:

$L R D_{m, r}=\frac{\theta_{m r}(1)}{\theta_{r r}(1)}$

with $\mathrm{LRD}_{m, r}$ being interpreted as the long-run elasticity of $m$ with respect to $r$. In fact, under the Fisher and Seater (1993) identification scheme, which assumes that $r$ is exogenous in the long run, $\theta_{m r}(1) / \theta_{r r}(1)$ can be interpreted as $\lim _{k \rightarrow \infty} b_{k}$, where $b_{k}$ is the coefficient from the regression:

$\left[\sum_{j=0}^{k} \Delta^{\langle m\rangle} m_{t-j}\right]=a_{k}+b_{k}\left[\sum_{j=0}^{k} \Delta^{\langle r\rangle} r_{t-j}\right]+e_{k t}$

and for $\langle m\rangle=\langle r\rangle=1$, consistent estimate of $b_{k}$ can be derived by applying ordinary least squares to the regression

$m_{t}-m_{t-k-1}=a_{k}+b_{k}\left[r_{t}-r_{t-k-1}\right]+e_{k t}$,

$k=1, \ldots K$ 
Based on Equation (16) and for a value of $k=30$ as used by Serletis and Yavari (2004 and 2005), our estimate of the interest rate elasticity, $\eta$, is 0.1073 and interest semi-elasticity $\xi$ is $1.0099,{ }^{7}$ which, in turn, are much lower than the corresponding values of 0.2088 and 2.1991, obtained by Gupta and Uwilingiye (2008) based on the Johansen (1991 and 1995) methodology.

Once we obtain the estimated values for $\eta$ and $\xi$, using long-horizon regression, we calculate the values of $A$ and $B$ so that the curves obtained pass through the geometric means of the data. This gives us values of $A=0.4255$ and $B=0.6035$. Note that the values for $\mathrm{A}$ and
B obtained by Gupta and Uwilingiye (2008), based on the co-integrating relationships, were respectively 0.3323 and $0.6862 .^{\circ}$

Having obtained the estimates for $\eta$ and $\xi$ and the values for $A$ and $B$, we are now in a position to obtain the welfare cost estimates of inflation, using both Bailey's (1956) consumer surplus approach and Lucas's (2000) compensating variation method. The results are reported in Table 2. Note that for the sake of comparison we also present the welfare cost estimates, based on the values of $\eta, \xi, A$ and $B$, obtained by Gupta and Uwilingiye (2008), based on the Johansen (1991 and 1995) approach.

\section{Table 2}

Welfare cost estimates

\begin{tabular}{|c|c|c|c|c|c|c|c|c|}
\hline \multicolumn{5}{|c|}{ Consumer surplus method } & \multicolumn{3}{c|}{ Compensating variation method } \\
\hline \multicolumn{3}{|c|}{ Johansen approach } & \multicolumn{2}{c|}{ Long-horizon } & Johansen approach & \multicolumn{2}{c|}{ Long-horizon } \\
\hline $\begin{array}{c}\text { Inflation } \\
\text { rate }\end{array}$ & Log-log & Semi-log & Log-log & Semi-log & Log-log & Semi-log & Log-log & Semi-log \\
\hline 3 & 0.0034 & 0.0034 & 0.0018 & 0.0015 & 0.0037 & 0.0035 & 0.0019 & 0.0016 \\
\hline 6 & 0.0067 & 0.0076 & 0.0035 & 0.0035 & 0.0072 & 0.0079 & 0.0037 & 0.0036 \\
\hline 10 & 0.0108 & 0.0143 & 0.0057 & 0.0068 & 0.0117 & 0.0149 & 0.0062 & 0.0070 \\
\hline 15 & 0.0156 & 0.0241 & 0.0084 & 0.0118 & 0.0172 & 0.0251 & 0.0092 & 0.0123 \\
\hline
\end{tabular}

Based on the results reported in columns 2 and 3 , and 4 and 5, the welfare cost estimates obtained under the consumer surplus approach, for 3 percent, 6 percent, 10 percent and 15 percent of inflation, using the Johansen (1991 and 1995) cointegration method and the longhorizon regression approach respectively, we see that welfare costs are substantially lower in the latter case. In fact, they are less by more than half of the costs obtained using the cointegration approach for both the log$\log$ and the semi-log specifications. When we compare Columns 6 and 7, and 8 and 9, we obtain a similar picture for the welfare cost estimates obtained using the compensating variation approach. Further, the welfare cost estimates within a specific estimation method, but across the consumer surplus approach and the compensating variation approach, are quite similar, with the figures being slightly higher under the compensating variation method outlined by Lucas (2000). Specifically, for the $\log -\log$ (semi-log) specification, estimated using the cointegration approach, under the consumer surplus approach [compensating variation approach], an increase in the inflation rate from 3 percent to 6 percent would increase the welfare cost from 0.67 percent of GDP to 1.08 percent of GDP [0.72 percent of GDP to 1.17 percent of GDP] ( 0.76 percent of GDP to 1.43 percent of GDP [0.79 percent of GDP to 1.4449 percent of GDP]). Under the long-horizon approach, the welfare cost estimates range between 0.18 percent of GDP and 0.35 percent of GDP and 0.19 percent of GDP to 0.37 percent of GDP with the loglog specification, obtained from the consumer surplus and the compensating variation approaches respectively, for an increase in the inflation rate from 3 percent to 6 percent. 
The corresponding values under the semi-log specification, for the same increase in the rate of inflation, are 0.15 percent of GDP to 0.35 percent of GDP and 0.16 percent of GDP to 0.36 percent of GDP. The bottom line is that, as in Serletis and Yavari (2004 and 2005), we find that the welfare cost estimates based on the long-horizon approach tend to be much smaller in comparison with other standard econometric methods of arriving at the long-run equilibrium relationship between the ratio of money balance to income and the nominal interest rate. The reason for this is that, under the long-horizon approach, estimates of interest rate elasticity and semi-elasticity tend to be comparatively lower. Given the fact that welfare cost estimates based on money demand estimations critically hinge on the size of interest rate elasticity and semi-elasticity, this brings down the welfare cost of inflation when compared to estimates obtained via econometric methods, such as the Johansen (1991 and 1995) approach.

\section{5}

\section{Conclusion}

In this paper, using the Fisher and Seater (1993) long-horizon approach, we estimate the long-run equilibrium relationship between money balance as a ratio of income and the Treasury bill rate for South Africa over the period 1965:02 to 2007:01, and, in turn, use the obtained estimates of the interest elasticity and the semi-elasticity to derive the welfare cost estimates of inflation, using both Bailey's (1956) consumer surplus approach and Lucas's (2000) compensating variation approach. When the results are compared with welfare cost estimates obtained recently by Gupta and Uwilingiye (2008), using the same data set, but based on Johansen's $(1991,1995)$ cointegration technique, the values are less by more than half of those obtained in the latter study. The paper highlights the fact that welfare cost estimates of inflation are sensitive to the methodology used to estimate the long-run equilibrium money demand relationships.

At this stage two aspects of the obtained results need further emphasis. First, when compared with the literature, the welfare cost estimates obtained for South Africa, whether based on the long-horizon regression or the Johansen (1991 and 1995) cointegration approach, are relatively higher in comparison with estimates available in the literature for other economies for similar levels of inflation rates. Second, it must be realised that whatever the estimation methodology used, whether it is a consumer-surplus approach or a compensating variation method, based on our estimates, we can conclude that the SARB's current inflation target band of 3-6 percent provides a reasonably good approximation in terms of welfare, at least when compared with a Friedman (1969)-type deflationary rule of zero nominal rate of interest.

However, the following question is undeniably relevant: Given that welfare cost estimates are sensitive estimation methodologies and seem to vary considerably according to the econometric approach undertaken, what is the true size of the welfare cost of inflation in South Africa? The answer to this question is difficult. However, it must be admitted that econometric methodologies deriving welfare cost measures by estimating money demand relationships provide only the lower bounds of the welfare cost of inflation. Welfare cost estimates merely measure the distortion in the money demand due to positive nominal interest rates. But, as argued by Dotsey and Ireland (1996), in a general equilibrium framework, a rise in the inflation rates can distort other marginal decisions and can negatively impact on both the level and the growth rate of aggregate output. In addition, as pointed out by Feldstein (1997), interactions between inflation and a non-indexed tax code can add immensely to the welfare cost of inflation. Given these two additional sources of inflation costs, there is no denying the fact that larger gains can conceivably be achieved by reducing the inflation target below 3 percent, the lower limit of the current inflation target band.

\section{Endnotes}

1 There were two reasons for the authors' decision to place more confidence in the log-log model of money demand. First, the $R^{2}$ and the Adjusted $R^{2}$ values of the inverse money demand relationship 
captured by the log-log specification were higher than the corresponding values of the semi-log model. Second, although there existed overwhelming evidence suggesting the choice of two lags for the semi-log specification, no cointegration could be detected using the Johansen test with two lags. The authors therefore had to use 4 lags, based on the Sequential Modified LR test statistic to obtain a stable long-run money demand relationship.

2 See Serletis and Virk (2006) for the sensitivity of the welfare cost estimates to the choice of monetary aggregation procedure.

3 The calculations were done using the DSolve routine in Mathematica, Version 5.

4 See Gupta and Uwilingiye (2008) for details regarding the reasons for the choice of M3 as the appropriate monetary aggregate for South Africa over the narrower aggregates generally used in literature. Basically, the authors indicate that the ratio of M3 to GDP is less volatile than the corresponding ratios of M1 and M2 to GDP. Further, M3 was used to account for the financial innovations that took place in the South African economy over the sample period used.

5 We also use the percentage change at seasonally adjusted annualised rates of the CPI to obtain the rate of inflation, hence the real rate of interest. See below, for further details.

6 The reader is referred to Gupta and Uwilingiye (2008) for the tests on stationality and cointegration on the variables of the model reported in Tables 1 through 3 .

7 Both the estimates of $\eta$ and $\xi$ are significant at the 1 percent level of significance.

8 Based on the suggestions of one of the anonymous referees, equation (16) was re-estimated without the constant. The corresponding values of the interest rate elasticity, $\eta$, was found to be 0.0965 and that of the interest semi-elasticity $\xi$ was 0.9556. Note that both these values were found to be significant at the 1 percent level. Given that the values of $\mathrm{A}$ and $\mathrm{B}$ would remain the same as above, we would obtain even lower estimates of the welfare cost of inflation under the two alternative specifications of money-demand.

\section{References}

BAILEY, M.J., 1956. The welfare cost of inflationary finance. Journal of Political Economy, 64: 93-110. BROCK, W., 1974. Money and growth: the case of long-run perfect foresight. International Economic Review, 15: 750-777.
CAGAN, P., 1956. The monetary dynamics of hyperinflation. In Milton Friedman, (ed). Studies in the quantity theory of money. Chicago: University of Chicago Press.

DOTSEY, M. \& IRELAND, P.N., 1996. The welfare cost of inflation in general equilibrium. Journal of Monetary Economics, 37: 29-47.

ENGLE, R.F. \& GRANGER, C.W., 1987.

Cointegration and error correction: representation, estimating and testing. Econometrica, 55: 251-276. FELDSTEIN, M., 1997. The costs and benefits of going from Llw inflation to price stability. In Romer, C.D. and Romer, D.H. (eds). Reducing inflation: motivation and strategy. Chicago: University of Chicago Press. FISCHER, S., 1981. Towards an understanding of the costs of inflation: II. Carnegie-Rochester Conference Series on Public Policy, 15: 5-41.

FISHER, M. \& SEATER, J., 1993. Long-run neutrality and superneutrality in an ARIMA framework.

American Economic Review, 83:402-415.

FRIEDMAN, M., 1969. The optimum quantity of money. In The optimum quantity of money and other essays, Chicago: Aldine Publishing Company. GOLDFELD, S.M., 1976. The case of missing money. Brookings Papers on Economic Activity, 7: 683-740. GUPTA, R. \& UWILINGIYE, J., 2008. Measuring welfare cost of inflation in South Africa. South African Journal of Economics, 76:16-25.

IRELAND, P.N., 2008. On welfare cost of inflation and the recent behaviour of money demand. NBER Working Paper, No. WP14098.

JOHANSEN, S., 1991. Estimation and hypothesis testing of cointegration vectors in Gaussian vector autoregressive models, Econometrica, 59:1551-1580. JOHANSEN, S., 1995. Likelihood-based inference in cointegrated vector autoregressive models, Oxford: Oxford University Press.

LUCAS, R.E. Jr, 1981. Discussion of: Stanley Fischer, towards an understanding of the costs of inflation II. Carnegie-Rochester Conference Series on Public Policy, 15:43-52.

LUCAS, R.E. Jr, 2000. Inflation and welfare.

Econometrica, 68:247-274.

MELTZER, A.H., 1963. The demand for money: the evidence from the Time series, Journal of Political Economy, 71:219-246.

PHILLIPS, P.C.B. \& SOULIARIS, S., 1990.

Asymptotic properties of residual based tests for cointegration. Econometrica, 58:165-193.

SERLETIS, A. \& YAVARI, K., 2004. The welfare cost of inflation in Canada and the United States. Economics Letters, 84: 199-204.

SERLETIS, A. \& YAVARI, K., 2005. The welfare cost of inflation in Italy. Applied Economics Letters, 12: 165-168. 
SERLETIS, A. \& VIRK, J.J., 2006. Monetary aggregation, inflation and welfare. Applied Financial Economics, 16: 499-512.

SERLETIS, A. \& YAVARI, K., 2007. On the welfare cost of inflation in Europe. Applied Economics Letters, 14: 111-113.
SIDRAUSKI, M., 1967. Rational choice and patterns of growth in a monetary economy. American Economic Review, 57: 534-544. 